\title{
Dengeli ROB translokasyonu (14;21) olan bir kadın: Olgu sunumu
}

\author{
Ali Karaman ${ }^{1}$, Paşa Uluğ ${ }^{2}$
}

\begin{abstract}
ÖZET:
Dengeli ROB translokasyonu $(14 ; 21)$ olan bir kadın: Olgu sunumu

Sitogenetik çalışmalar, spontan abortusda çok sayıda kadında açıklayıcı özelliğe sahiptir. Aile hikayesi, pedigri analizi ve parental karyotipler risk tahmininde temel faktörlerdir. Bu çalışmada, rob(14;21) (q10;q10) olan bir annenin klinik özeliği literatür bilgileri ışığında sunulmuştur. Habituel abortus sebebiyle laboratuarımıza gönderilen bir ailenin, konvansiyonel sitogenetik tekniklerle incelemeleri yapıldı. Sitogenetik analiz sonucunda annenin karyotipi 45,XX, rob(14;21)(q10;q10) olarak tespit edildi. Babanın karyotipi normal idi $(46, X Y)$.

Anahtar kelimeler: Habituel abortus, robertsonian translokasyon, down sendromu

\section{ABSTRACT:}

A woman with balanced ROB translocation $(14 ; 21)$ : case report

Cytogenetic studies have revealed more number of females in spontaneous abortion. Family history, analysis of pedigree, and karyotypes of the parents are the basic factors at estimating the risks. In this study, the clinical feature of the $\operatorname{rob}(14 ; 21)(q 10 ; q 10)$ with mother is presented based on the literature. Family members were sent to laboratory of medical genetics because of habitual abortus. Conventional cytogenetic techniques were performed for these patients. The karyotype of the mother was found as $45, X X, \operatorname{rob}(14 ; 21)$ (q10q10). The karyotypes of the father was normal $(46, X Y)$.

Key words: Habituel abortus, robertsonian translocation, down syndrome
\end{abstract}

Ş.E.E.A.H. Tıp Bülteni 2013;47(2):87-90
'Erzurum Nenehatun Kadın Doğum hastanesi, Genetik Ünitesi, 25070, Erzurum-Türkiye Erzurum Nenehatun Kadın Doğum hastanesi, Kadın Doğum Kliniği, 25070, Erzurum-Türkiye

Yazışma Adresi / Address reprint requests to: Dr. Ali Karaman, Erzurum Nenehatun Kadın Doğum Hastanesi, Genetik Ünitesi, 25240, Erzurum-Türkiye

Telefon / Phone: +90-442-317-2295/1145

E-posta / E-mail:

alikaramandr@hotmail.com

Geliş tarihi / Date of receipt: 23 Eylül 2011 / September 23, 2011

Kabul tarihi / Date of acceptance: 25 Aralık 2011 / December 25, 2011

\section{GiRiş}

Habituel abortus, birbirini izleyen en az iki ya da daha fazla gebeliğin 20. gebelik haftasından önce spontan sonlanması olarak tanımlanmaktadır.(1) Habituel abortusun etyolojisi geniş bir spektrum sergileyebildiğinden, nedenin belirlenmesi uzun ve maliyetli çalışmalar gerektirmektedir.(2) Habituel abortusların yaklaşık \%38 kadarı idiopatiktir. Habituel abortus etyolojisinde rol alan faktörler: genetik nedenler (\%20) (kromozom anomalileri, herediter trombofili, tek gen hastalıkları ve multifaktöriyel hastalıklar), endokrin faktörler (\%15), otoimmün hastalıklar (\%15), anatomik faktörler (\%10) ve enfeksiyonlar $(\% 2) \operatorname{dir}(1,3)$.

Robertsonian translokasyonlar (rob) insanlarda en sık görülen yapısal yeniden düzenlenmelerdir. Down sendromunu da içeren mental retardasyona önemli katkısı vardır. Down sendromlu bireylerin yaklasık $\% 5$ 'inde anöploidi, kromozomal bir yeniden düzenlenmeden kaynaklanır. Bunların \%95'i Robertsonian translokasyonlardır. Rob(14q;21q) ve $(21 q ; 21 q)$ arasındaki yeniden düzenlenmeler [rearrangement(rea) (21q;21q)] yaklaşık olarak eşit frekansta oluşmasına rağmen, rob(14q;21q)'ların yaklaşık yarısı taşıyıcı bir ebeveynden kalıtılırken, yeniden düzenlenme (21q;21q)'ların çoğu (\%95) de novo olarak oluşmaktadır (4).

Burada rob(14q;21q) dengeli taşıyıcısı olan bir anne ile habituel abortusların etiyolojisi tartışılmıştır.

\section{OLGU}

Habituel abortus nedeniyle laboratuarımıza gönderilen annenin yaşı 25 ve babanın yaşı 27 idi. Olgumuzda görülen düşüklerin hepsi gebeliklerinin 1. tri- 
mestirinde meydana gelmişti. Çiftin periferik kan kültürlerinde yapılan sitogenetik inceleme sonucunda, karyotipleri $45, X X, \operatorname{rob}(14 ; 21)(q 10 ; q 10)$ ve $46, X Y$ olarak tespit edildi. Hastaların karyotipleri için heparinli enjektörlere $2 \mathrm{ml}$ periferik kan alındı. Alınan kan örneklerinden \%2 Phytohemaglutinin (PHA) ilave edilen $5 \mathrm{ml}$ karyotyping mediuma ekim yapılarak 72 saat kültüre edildi. Kültür sonrası tripsin giemsa bantlama yöntemi (GTG) kullanılarak boyanan preparatlar ışık mikroskobunda incelendi (Resim 1). Her bir preparatda en az 30 metafaz değerlendirildi. Karyotipik analizlerini takiben aileye genetik danışmanlık verildi. Aileden bilgilendirilmiş olur formu alındı.

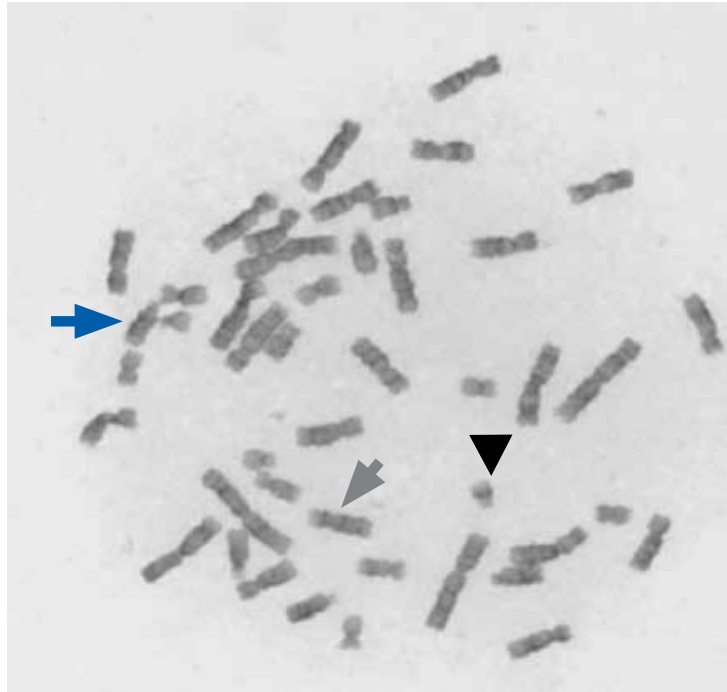

Şekil 1: Olgumuzun kromozom yapısı, 45,XX,rob(14;21) (q10;q10): Gri ok: $\operatorname{der}(14 ; 21) ;$ mavi ok: kromozom 14'ü; siyah ok: kromozom 21'i göstermektedir.

\section{TARTIŞMA}

Gebeliklerin yaklaşık \%15'i klinik düşükle sonlanırken, çiftlerin yaklaşık \%1'inde habituel abortus görülebilir. Habituel abortus; 20. gebelik haftasından önce birbirini izleyen en az iki veya daha fazla gebeliğin spontan olarak sonlanmasıdır. Habituel abortuslar obstetrikte etiyolojik ve prognostik faktör tayininde yetersiz kalınan konulardan biridir (5). Habituel abortus etiyolojisinde bilinen bir çok sebep vardır. Serviks yetersizliği ve uterusun yapısal bozuklukları (myomlar, uterus içi adezyonları, uterus septumu ve uterus didelfis), endokrin nedenler (diyabet, tiroid bezi hastalıkları, corpus luteum yetmezliği) ve enfek- siyonlar (listeria monocytogenes, toksoplasma gondii, mycoplasma genithalum, ureaplasma urealiticum, chlamydia trachomatis, cytomegalovirus, rubella, herpes simpleks virus, measles virüs ve coxsackie virüs) habituel abortusa neden olan önemli faktörlerdir (1-3,6).

Habituel abortus görülen ailelerde trombofili insidansı \%60'lara kadar çıkabilmektedir. Herediter ve/ veya kazanılmış trombofilik bozukluklar ve antifosfolipid antikorlar nedeniyle gelişen plasental vasküler tromboz, tekrarlayan gebelik kayıpları ve gebelik komplikasyonları riskini önemli oranda arttırmaktadır (3). Gebeliğin başarılı gidişatı için etkili bir uteroplasental dolaşım şarttır ve bu dolaşım hemostaz bozukluklarından etkilenebilir. Bu yüzden maternal trombofililer (Faktör V Leiden, protrombin mutasyonları, protein $\mathrm{C}$, protein $\mathrm{S}$ eksiklikleri) obstetrik açıdan önemli patolojilerdir. Rekürrent fetal kaybı olan bazı hastalarda herediter ve edinsel aktive protein C (APC) rezistansının vasküler plasental yetmezliğin potansiyel sebepleri arasında olduğu ileri sürülmektedir. Literatürde Faktör V Leiden G1691A ve protrombin G20210A, metilentetrahidrofolat Redüktaz (MTHFR) C677T ve A1298C mutasyonlarının habituel abortusla ilişkili olduğunu destekleyen çalışmalar mevcuttur (7-9).

Habituel abortus anne yaşıyla artmaktadır. 35 yaş üzeri kadınlarda genç kadınlara oranla normal gebelik ihtimali büyük ölçüde azalır. 40 yaşın üzerindeki kadınlarda düşük riski \%50'ye yaklaşır. Kadınlar bu riskler konusunda eğitilmelidir. Ayrıca habituel abortus etyolojisinde önemli yer tutan idiyopatik tekrarlayan gebelik kayıplarında, yaşam tarzının (sigara, içki, kafein kullanımı) etkili olabileceği bildirilmektedir (3).

Habituel abortus etyolojisinde genetik faktörler yaklaşık \%20 oranında rol oynamaktadır. Bu faktörler arasında eşlerde ve fetüste kromozomal anomaliler, tek gen hastalıkları, tromboza yatkınlık genlerindeki mutasyonlar ve multifaktöriyel değişiklikler bulunmaktadır $(3,10)$. Genetik anomaliler fetal veya parental kaynaklı olabilmektedir $(1,11)$. Gebelik kayıplarının \%80'inden fazlası birinci trimesterde meydana gelmekte ve bu vakaların \%53'ünde kromozom anomalisi saptanmaktadır.Tekrarlayan düşüklere neden olan fetal anomalilerin araştırılması amacıyla abortus materyalinden, amnion sIVISI, corion villus biopsisi ve kordon kanından kromozom 
analizleri yapılmaktadır (2,3). Eşlerde periferik kandan yapılan kromozom analizleri normal bulunmasına rağmen gonadal mozaisizme bağlı olarak fetüste veya embriyoda kromozom anomalileri ortaya çıkabilmekte ve sonraki gebeliklerde tekrar edebilmektedir. Bu nedenle tekrarlayan gebelik kayıpları etiyolojisinin araştırılmasında, ebeveynlere yapılan kromozom analizinin yanısıra, abortus materyalinden de sitogenetik çalışma yapılması gerekmektedir. Kromozom analizi sonuçlarına göre ebeveyne genetik danışma hizmeti verilmesi ve ailenin bir sonraki hamilelik için prenatal tanı programına alınması gerekebilmektedir. Tekrarlayan gebelik kayıpları öyküsü olan eşlerde kromozom anomalisi saptanma sıklığı \%3-10 olarak bildirilmiştir $(2,3)$.

Fetüste kromozom anomalisinin meydana gelme riski; ebeveynlerde saptanan kromozom anomalisi tipine ve anomalinin maternal ya da paternal kaynaklı oluşuna göre değişmektedir. Bu nedenle tekrarlayan gebelik kayıpları yaşayan bireylerin sonraki gebeliklerinde izlenecek yolun belirlenmesi açısından eşlerde kromozom analizinin yapılması gerekmektedir $(2,3)$. Vakamızda rob(14q;21q) dengeli taşıyıcılığı görülmüştür. Robertsonian translokasyonlar, akrosentrik kromozomlar arasında, tüm kol değişimi sonucu oluşurlar. İnsanlarda 13, 14, 15, 21 ve 22 nolu kromozomlar arasında gerçekleşir (12). İki akrosentrik kromozomun sentrik füzyonu olan Robertsonian translokasyonlar genel populasyonda 1000 'de bir sıklıkla oluşurlar. En sık rastlanan formu iki homolog olmayan kromozom arasında gerçekleşen tipidir. En sık olarak da 13 ve 14 nolu kromozomları arasında meydana gelir. Bu durumda translokasyon tipi trizomi 13 görülmektedir. Tranlokasyon tipi trizomi 14 ise ilk trimester kaybı ile sonuçlanmaktadır. Robertsonian translokasyonlu bireylere mutlaka prenatal tanı önerilmelidir (13).

Rob taşıyıcıları, fenotipik olarak normal olmasına rağmen, doğum defektlerine yol açan, anöploid yavruya sahip olma ihtimalleri yüksektir. Hem homolog olmayan kromozomlar arasında [rob(14q;21q)], hem de homolog kromozomlar arasında [rea $(21 q ; 21 q)$ ] Robertsonian translokasyonlar, Down sendromunda görülebilmektedir. Down sendromunda en sık görülen bu iki anomali, yani rea(21q;21q) ve rob(14q;21q), eşit sıklıkta görülmektedir. Homolog olmayan kromozomlar arasındaki rob'lar içinde en sık olarak \%82 sıklıkla rob(14q;21q) meydana gelmektedir. Homolog rob'lardan rea(21q;21q)'nun \%95'inden fazlası ise denovo gelişir (13). Down sendromunun \%90'ו, ebeveynlerden birinde gametogenez esnasında kromozom 21'in ayrılamama hatasından kaynaklanan klasik trizomi $21^{\prime}$ den oluşmaktadır. Yaklasık olarak \%6-7'si mozaik tip ve \%3-4'ü kromozom 21 ile D ya da G grubu kromozomlar arasındaki translokasyondan kaynaklanmaktadır (14).

Tekrarlayan gebelik kayıplarında en önemli rolü kalıtsal faktörler oynamaktadır. Ailenin sonraki gebeliklerinde izleyeceği yolun belirlenmesi amacıyla; etiyolojik faktörlerin aydınlatılması ve kalıtım şeklinin belirlenmesi önerilmektedir. Tekrarlayan gebelik kaybı etiyolojisinin aydınlatılması sürecinde öncelikle karyotipleme ve trombofili analizlerinin yapılması gerekmektedir. Düşük riski, düşük sayısı arttıkça artar. Üst üste 4 düşükten sonra tekrarlama riski \%50'ye kadar yükselmektedir. Hastalar çoğunlukla herhangi bir bulgu olmasa da kaybın anne yaşıyla birlikte artacağı konusunda eğitilmelidir. Genellikle 35 yaş altındaki kadınlarda üç düşükten, daha ileri yaştakilerde ise iki düşükten sonra laboratuar çalışmaları yapılmalıdır.

\section{KAYNAKLAR}

1. Ford HB, Schust DJ. Recurrent Pregnancy Loss: Etiology, Diagnosis, and Therapy. Rev Obstet Gynecol. 2009; 2(2):76-83.

2. Carp HJA. Recurrent Miscarriage: Genetic Factors and Assessment of the Embryo. IMAJ 2008; 10:229-231.

3. Güven E, Güven S, islamoğlu GA, Demir B, Serdar Günalp S. Tekrarlayan Gebelik Kayıplarında Güncel Algoritma. Hacettepe Tıp Dergisi 2006; 37:117-123.

4. Shaffer LG, McCaskill C, Haller V, Brown JA, Jackson-Cook CK. Further characterization of 19 cases of rea(21q21q) and delineation as isochromosomes or Robertsonian translocations in Down syndrome. Am J Med Genet 1993; 47:1218-1222.

5. Clark DA, Lea RG, Podor $T$, et al. Cytokines determining the success or failure of pregnancy.Ann NY Acad Sci 1991; 626: 524-536.

6. Sugiura-Ogasawara M, Ozaki Y, Kitaori T, Kumagai K, Suzuki $S$. Midline uterine defect size is correlated with miscarriage of euploid embryos in recurrent cases. Fertil Steril. 2010; 93(6):1983-1988.

7. Preston FE, Rosendaal FR, Walker ID, et al. Increased fetal loss in women with heritable thrombophilia. Lancet 1996; 348:913916. 
8. Brenner B, Mandel $H$, Lanir $N$, et al. Activated protein $C$ resistance can be associated with recurrent fetal loss. $\mathrm{Br} J$ Haematol 1997; 97: 551-554.

9. Franco RF, Trip MD, ten Cate $\mathrm{H}$, et al. The $20210 \mathrm{G}$ A mutation in the 3' untranslatedregion of the prothrombin gene and the risk for arterial thrombotic disease. B J Haematol 1999; 104: 50-54.

10. Suzumori N, Sugiura-Ogasawara M. Genetic factors as a cause of miscarriage. Curr Med Chem. 2010;17(29):3431-7.

11. Cunningham FG., Leveno KJ. McGraw-Hill. 22nd Edition. Williams Obstetrics. 2005. Sf. 232-236, 1074-1079.
12. Bandyopadhyay R, McCaskill C, Knox-Du Bois C, et al. Mosaicism in a patient with Down syndrome reveals postfertilization formation of a Robertsonian translocation and isochromosome. Am J Med Genet A 2003; 116:159-163.

13. Scriven PN, Flinter FA, Braude PR, Ogilvie CM. Robertsonian translocations-reproductive risks and indications for preimplantation genetic diagnosis. Hum Reprod 2001;16:22672273.

14. Jyothy A, Rao GN, Kumar KS, et al. Translocation Down syndrome. Indian J Med Sci 2002; 56:122-126. 